\title{
Percepção ambiental no contexto das representações sociais: um estudo de caso na periferia de Fortaleza, Ceará
}

\author{
Percepción ambiental en el contexto de las representaciones \\ sociales: un estudio de caso en la perifería de Fortaleza, Ceará
}

\author{
Environmental Perception in the Context of Social \\ Representations: a Case Study in the Periphery of Fortaleza, \\ Ceará
}

\author{
Fábio Soares Guerra \\ fabiosoaresguerra@hotmail.com \\ Universidade Federal do Ceará, Fortaleza, CE \\ Suedio Alves Meira \\ suediomeira@gmail.com \\ Universidade Federal do Ceará, Fortaleza, CE \\ Nágila Fernanda Furtado Teixeira \\ fernandaft92@gmail.com \\ Universidade Federal do Ceará, Fortaleza, CE \\ Edson Vicente da Silva \\ cacauceara@gmail.com \\ Universidade Federal do Ceará, Fortaleza, CE
}

Resumo: Este estudo teve por objetivo investigar as variáveis da percepção ambiental dos moradores do bairro Conjunto Ceará, localizado no subúrbio da cidade de Fortaleza, utilizando a Teoria das Representações Sociais. O pressuposto básico dessa investigação é que por meio das representações que fundamentam a percepção popular pode-se categorizar as práticas socioambientais cotidianas. Constatou-se que o bairro se apresenta espacialmente multifacetado e socialmente segregado. Além do mais, seus moradores possuem aguçada percepção ambiental em vários aspectos, apropriandose a contento do seu espaço de vivência desenvolvendo forte vínculo afetivo com o mesmo que, por sua vez, condiciona as práticas sociais, o modo de pensar e sentir o Conjunto Ceará.

Palavras-chave: Percepção Ambiental, Representação Social, Geografia da Percepção.

Resumen: El objetivo de este estudio fue investigar las variables de la percepción ambiental de los habitantes del barrio Conjunto Ceará, ubicado en el suburbio de la ciudad de Fortaleza, teniendo como subsidio la Teoría de las Representaciones Sociales. El supuesto básico de esta investigación es que a través de las representaciones que fundamentan la percepción de los populares se pudo categorizar las prácticas socioambientales cotidianas. Se constató que el barrio se presenta espacialmente multifacético y socialmente segregado. Además, sus habitantes poseen aguda 
percepción ambiental en varios aspectos, apropiándose a contento de su espacio de vivencia desarrollando fuerte vínculo afectivo con el mismo que, a su vez, condiciona las prácticas sociales, el modo de pensar y sentir el Conjunto Ceará.

Palabras-clave: Percepción Ambiental, Representación Social, Geografía de la Percepción.

\begin{abstract}
This study aimed to investigate the environmental perception variables of residents of the Conjunto Ceará, in the suburbs of Fortaleza city, employing the Theory of Social Representations. The basic assumption of this research is that through the representations that underpin the perception of the people, it was possible to categorize everyday socio-environmental practices. It were verified that the neighborhood presents itself spatially multifaceted and socially segregated. Moreover, its residents have keen environmental awareness in various aspects, appropriating to the content of their living space developing a strong affective bond with the same that, in turn, condition social practices, the way of thinking and feeling the Conjunto Ceará.
\end{abstract}

Key words: Environmental Perception, Social Representation, Perception Geography.

\title{
INTRODUÇÃO
}

O estudo da percepção em Geografia mostra-se impreterível diante do cenário socioambiental apresentado na contemporaneidade. A periferia de Fortaleza, capital do estado do Ceará, em particular o bairro Conjunto Ceará, vive as contradições sociais e naturais resultantes da imposição dos interesses econômicos que se sobrepõem às necessidades dos moradores.

Como essa realidade é percebida e internalizada? Quais as representações de meio ambiente estão sendo construídas e absorvidas, por quem e segundo quais interesses? Como a comunidade vivencia e responde ao contexto do bairro? O estudo da percepção ambiental lança luz sobre essas indagações e gera subsídios à gestão e ao planejamento do espaço urbano.

Assim sendo, nesta pesquisa o objetivo foi investigar as variáveis da percepção ambiental dos moradores do bairro Conjunto Ceará, localizado na periferia sudoeste da cidade de Fortaleza, tendo como suporte central a Teoria das Representações Sociais (MOSCOVICI, 1978), sendo a análise reforçada teoricamente por contribuições da Fenomenologia (MERLEAU-PONTY, 1999). Por conseguinte, procurou-se compreender como a população percebe e se apropria do próprio bairro (Fig. 1). Tece-se reflexões sobre as práticas socioespaciais, as expectativas, o modo de viver, pensar e sentir a realidade na qual estão inseridos. Ademais, dialoga-se sobre como a Educação Ambiental constitui ferramenta geradora de saberes para o convívio socioambiental. 
Figura 1 - Localização do bairro Conjunto Ceará no contexto suburbano de Fortaleza.

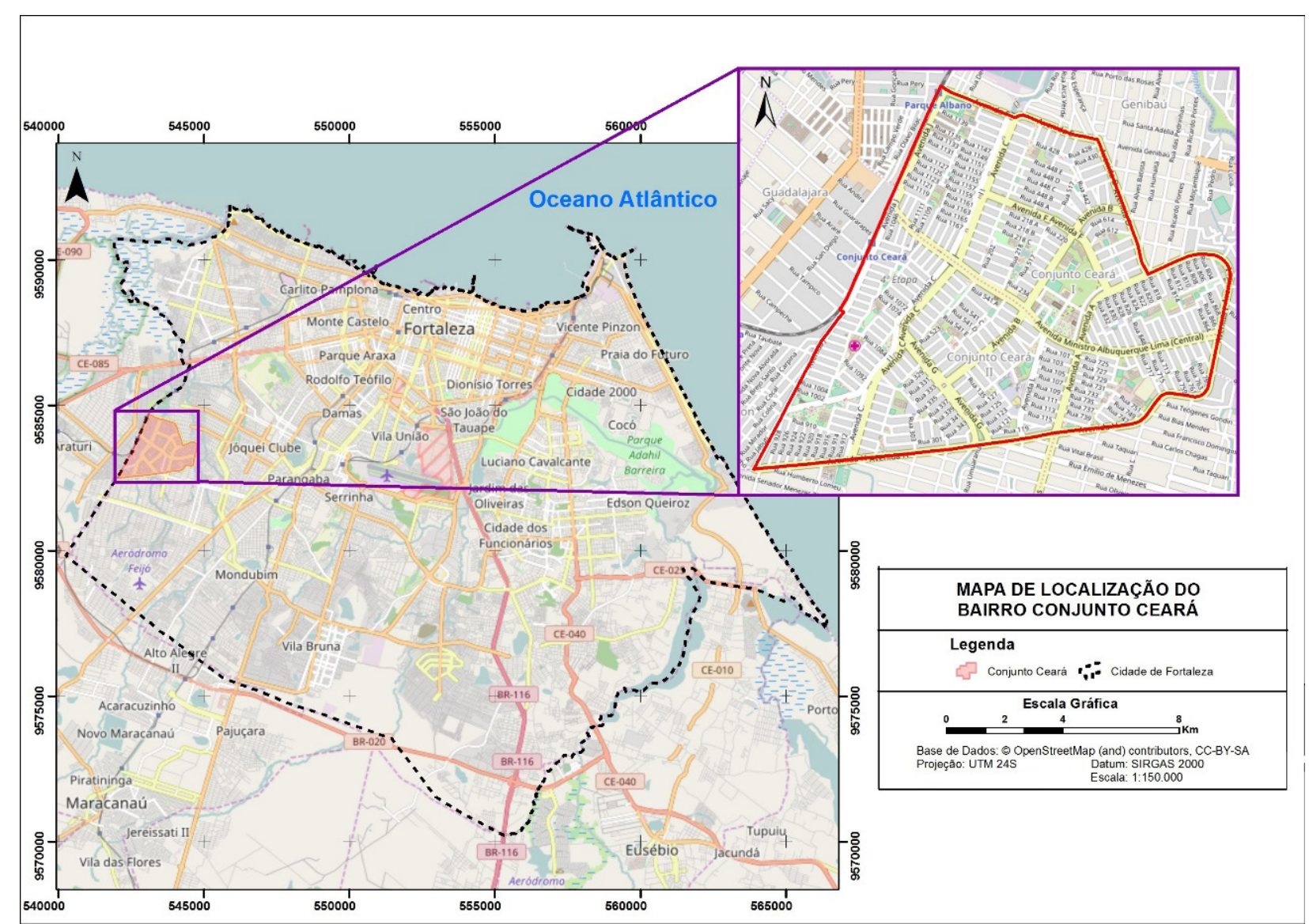

Fonte: Fábio Soares Guerra.

\section{METODOLOGIA}

Utilizou-se a abordagem qualitativa, através de séries de registros (manuscritos, fotográficos, gravações em áudio, questionários, entrevistas), quer a partir da bibliografia consultada, quer por meio da pesquisa de campo. A partir disso, empreendeu-se uma análise interpretativa buscando delinear como a população do Conjunto Ceará (base empírica da investigação) percebe, sente e lida com as questões socioambientais do local onde mora. O processo estruturante de investigação seguiu as etapas: exploratória, descritiva e explicativa, numa escala temporal relativa ao período de janeiro a junho de 2017.

A população amostral foi escolhida seguindo os critérios de distribuição espacial, tempo de moradia e acessibilidade pessoal. Selecionou-se aleatoriamente cinco pessoas de cada uma das quatro etapas de implantação do conjunto para garantir maior representatividade possível. Realizou-se, ademais, entrevistas em uma escola municipal, com uma professora de Geografia e cinco alunos do ensino fundamental, também escolhidos de forma aleatória.

Ao empreender as entrevistas estruturadas, por meio de formulários e questionários, foi indagado: tempo de moradia no bairro, a identificação socioespacial, a convivência com 
a canalização dos cursos d'água, as doenças oriundas da má gestão ambiental, a insegurança resultante do aumento da criminalidade, o vínculo afetivo desenvolvido.

As entrevistas não diretivas, por seu turno, foram realizadas face a face. Nesse caso, os moradores analisados ficaram à vontade para expressarem-se sobre o modo como veem e lidam cotidianamente com os problemas e as vantagens de morar no Conjunto Ceará, as formas de apropriação dos espaços públicos, a utilização dos recursos naturais, os sentimentos e perspectivas futuras. Foram realizados registros com gravador de áudio, com o consentimento dos entrevistados. Em seguida transcreveu-se as gravações para análise e referência ao longo do trabalho.

O desenho metodológico, em certa medida, viabilizou um trabalho de natureza aplicada, ao discutir e propor reflexões sobre um melhor convívio socioambiental, além da possibilidade de utilização da percepção ambiental como instrumento de auxílio ao gerenciamento do meio ambiente urbano.

\section{APONTAMENTOS EPISTEMOLÓGICOS PARA PERCEPÇÃO AMBIENTAL}

Para a análise das questões socioespaciais, principalmente depois de 1970, não raro a ciência geográfica tem recorrido à abordagem perceptiva como instrumento de investigação, explicação e proposição científica. Assim, a problemática da percepção em Geografia constitui-se em objeto de reflexão e pesquisas de importância significativa diante do contexto político, social e econômico vivenciado.

Os estudos citados apresentam diversificada base psicológica. Vários trabalhos "fundamentaram-se na teoria de Piaget, outros na de Skinner, e outros, ainda, na Gestalt. A maioria tem-se desenvolvido direta ou indiretamente sobre os conhecimentos preconizados por Piaget e seus colaboradores" (OLIVEIRA; MACHADO, 2010, p. 129). Por possuir uma sistemática abrangente, estruturada, de caráter dinâmico e alinhada à realidade contemporânea essa teoria tem correspondido bem às argumentações sobre a percepção, alçando luz sobre as respostas de comportamento diante ao meio ambiente. Ademais, trabalhar com a atividade perceptiva capacita entender como compreende-se e interage-se com o mundo à nossa volta. Aliás, “as noções básicas sobre percepção/ cognição implicam as de sensação, atividade perceptiva, imagem mental e a própria conduta humana relacionada com a afetividade e a representação" (OLIVEIRA, 2012, p. 56). O comportamento individual ou em grupo, independente de nível cultural ou econômico, nos fornece respostas as mais variadas indagações do transcurso espaço-temporal. Isso por si justifica a relevância científica da Teoria da Percepção Ambiental para os estudos socioambientais.

Todavia, não há consenso em relação as definições de percepção ambiental. Contudo, há um ponto de convergência entre elas - a preocupação com as implicações físico-sociais dos impactos ambientais. Entretanto, uma perspectiva de percepção ambiental que muito se aproxima do ponto de vista geográfico é expressa por Oliveira:

Quando se trata de percepção ambiental, trata-se, no fundo, de visão de mundo, de visão de meio ambiente físico, natural e humanizado, na maioria é sociocultural e 
parcialmente é individual; é uma experiência em grupo ou particularizada; é uma atitude, uma posição, um valor, uma avaliação que se faz do nosso ambiente. Ou seja, usando o neologismo da topofilia, para expressar os laços afetivos que desenvolvemos em relação ao nosso meio ambiente, direta ou simbolicamente (OLIVEIRA, 2012, p. 61).

Infere-se, no entanto, a percepção ambiental como meio pelo qual apreende-se os aspectos do entorno subjacente, o resultado da internalização de conhecimentos sobre esses espaços. Essa perspectiva analítica está relacionada à Geografia da Percepção que tem por objetivo superar os estudos reducionistas de influência econômica neoclássica (DINIZ, 2005).

Segundo Andrade (1987), a abordagem perceptiva apresenta duas vertentes: behaviorista e a humanista. A primeira questionava a análise do comportamento humano fundamentado no viés econômica e racional. Nesse caso, a percepção do ambiente configurava-se como ponto a partir do qual, no contexto da vivência espacial, as decisões são tomadas. A vertente behaviorista tem como teórico de destaque, Julian Wolpert.

No desenrolar de seus estudos, Wolpert (1965) associou a percepção ambiental aos conceitos de espaço-ação, de espaço-atividade e de utilidade espacial, para analisar o comportamento geral dos indivíduos em suas tomadas de decisões, tendo em vista a vivência dos mesmos em determinados espaços.

O espaço-ação é o conjunto de lugares de socialização cotidiana, no qual o indivíduo se transloca e decide acerca de suas práticas sociais, lugares com os quais se mostra bem familiarizado, por exemplo, a praça, a loja, a escola, o trabalho. É na vivência do espaço-ação, por meio de relações interpessoais e objetivas com o meio, que o indivíduo constrói a identidade social. Esta também será orientadora de condutas e sentimentos (DINIZ, 2005).

O espaço-atividade, por sua vez, configura uma parcela do espaço-ação. É o circuito dos lugares em que o indivíduo interage com maior frequência, sendo dividido em espaços hierárquicos na medida em que se aumenta a escala. Por exemplo, comunidade, bairro, cidade, região. Quanto maior a escala, menor tende de ser a familiaridade. É justamente nessa categoria espacial que o indivíduo desenvolve e utiliza, por meio do trabalho, mecanismos para sua subsistência, reprodução e realização (DINIZ, 2005).

A utilidade espacial, por outro lado, vai ser determinada de acordo com a relevância que cada lugar vai ter para cada indivíduo. A infraestrutura, a disponibilidade dos meios de transportes públicos, o acesso ao trabalho, a salubridade da moradia, o nível social da vizinhança, entre tantos outros aspectos, são levados em conta como critérios individuais de avaliação. Caso determinado lugar não alcance o patamar desejado, procura-se outro, ampliando assim o espaço-ação (DINIZ, 2005).

Por outro lado, a vertente humanista "sugere não só a introdução de novas bases filosóficas, como metodológicas às abordagens geográficas. Trata-se de uma visão de geografia humana centrada na percepção, criatividade, experiência e valores humanos" (DINIZ, 2005 , p. 3). Na abordagem humanista a subjetividade pauta as investigações. Mesmo que a relação mútua entre objeto e observador possa influenciar as conclusões das pesquisas, a aproximação do palpável, da concretude objetiva, faz-se preferível. 
Desta forma, a percepção, os valores, a criatividade, os referenciais e, sobretudo, a experiência humana são centralizadas como fundamento de análise. A busca pelas leis que regem o comportamento humano é relegada em detrimento da experiência individual. Yi-Fu Tuan (1980) trabalhou conceitos basais para os estudos socioespaciais, dentre eles: o de topofilia. Para a construção do mesmo a percepção ambiental é impreterível, uma vez que é resultante da vivência direta e indireta nos diversos contextos espaciais. Contudo, que relação pode-se estabelecer entre o conceito de topofilia e os estudos geográficos? Para Tuan, a expressão "[...] 'topofilia' é um neologismo, útil quando pode ser definida em sentido amplo, incluindo todos os laços afetivos dos seres humanos com o meio ambiente material" (TUAN, 1980, p. 107). Desta forma, topofilia se refere à afetividade que o indivíduo desenvolve em relação a um lugar. É um sentimento de pertencimento, um elo emocional para com o espaço vivido.

A topofobia, por seu turno, percorre o sentido contrário, representa repulsa ou aversão a certos lugares. As referidas categorias auxiliam na caracterização e compreensão das práticas ambientais e sociais evidenciadas pela comunidade estudada.

A Fenomenologia é outra corrente científica que fornece contribuições à Geografia da Percepção, ao levar em conta a própria percepção, a subjetividade e o mundo vivido como fundamentos básicos para os estudos socioespaciais. Merleau-Ponty (1999), um dos principais nomes dessa corrente de pensamento, aponta que a intencionalidade permeia a consciência, assinala o indivíduo em interação constante com as mais variadas vivências, no bojo do processo subjetivo. Destaca a necessidade da interdisciplinaridade e da não fragmentação das áreas do conhecimento.

Ao dissertar sobre a Fenomenologia, o autor argumenta que a mesma corresponde: "a tentativa de uma descrição direta de nossa experiência tal como ela é, e sem nenhuma deferência à sua gênese psicológica e às explicações causais que o cientista, o historiador ou o sociólogo dela possam fornecer" (MERLEAU-PONTY, 1999, p.12). A Fenomenologia questiona os fundamentos do racionalismo e do empirismo que vicia o método científico por buscar a compreensão através da objetividade e não considerar o sujeito enquanto ser perceptivo imerso na dimensão subjetiva. Daí a crítica à ciência moderna, pois o sentido da pesquisa está no âmago do próprio pesquisador, na relação tempo-espaço, na vivência no próprio mundo que é alvo da investigação. Essa perspectiva mostra-se como contraponto ao olhar da ciência objetiva. De fato, a Fenomenologia é fundamento teórico significativo para a Geografia da Percepção.

Percebe-se, então, que o campo de estudo da Geografia da Percepção engloba a subjetividade, a intuição e a experiência para explicar o mundo percebido, vivido e imaginado. Isso em consonância com a abordagem fenomenológica, pois a consciência de mundo é elaborada pela experiência concreta. Desta maneira, por meio da atividade perceptiva o indivíduo apreende e compreende objetos exteriores ao seu próprio mundo. Nesse ensejo, o conceito de espaço toma contornos diferenciados e expressivos para a análise científica. De acordo com Merleau-Ponty (2004, p. 17), do ponto de vista fenomenológico: 
A ideia de um espaço homogêneo completamente entregue a uma inteligência sem corpo é substituída pela ideia de um espaço heterogêneo, com direções privilegiadas, que têm relação com nossas particularidades corporais e com nossa situação de seres jogados no mundo.

Observa-se que essa conceituação destaca a relação do sujeito com o espaço por outro ponto de vista. A relação passa da categoria indivíduo-objeto no contexto espacial para a de indivíduo-espaço, ou seja, a relação entre o ser e o meio familiar torna-se o foco de investigação. Esse redimensionamento converge para as preocupações de estudo da Geografia da Percepção, onde as relações socioespaciais configuram-se como mediadora de comportamento e das representações sociais construídas sobre o próprio ambiente. Nessa tessitura, a abordagem fenomenológica da Geografia destaca:

O espaço é vivido e percebido de maneira diferente pelos indivíduos, uma das questões decisivas da análise geográfica que se coloca diz respeito às representações que os indivíduos fazem do espaço. Essa Geografia procurou demonstrar que para o estudo geográfico é importante conhecer a mente dos homens para saber o modo como se comportam em relação ao espaço (LENCIONI, 2003, p. 152).

Considerando o acima citado, o espaço vivido e concebido socialmente se evidencia como ponto focal da Geografia da Percepção, embasada pela Fenomenologia, onde seus valores e significados são destacados pelo viés humanista. A partir disso, pode-se correlacionar, por meio das representações sociais constantemente elaboradas e reelaboradas por intermédio da percepção, o estudo socioespacial às demais temáticas da ciência geográfica.

No entanto, o estudo do espaço transcende em muito a análise da visualização do concreto, posto que o mesmo se mostra permeado de simbologias e intencionalidades, estando relacionado com a percepção individual. Desta maneira, “o espaço não é ambiente (real ou lógico) em que as coisas se dispõem, mas o meio pelo qual a posição das coisas se torna possível" (MERLEAU-PONTY, 1999, p.328). Sendo assim, o espaço torna-se fruto do imaginário coletivo, da consciência social estando para além do palpável e do tangível. Não será, pois, o estudo da aparência e sim da essência que será priorizado. Essa perspectiva aproxima sujeito e objeto por meio do estudo da vivência pessoal, onde a subjetivação é o pano de fundo. Deste modo, o indivíduo é conduzido ao contato e a compreensão do mundo externo por meio da percepção.

\section{REPRESENTAÇÃO SOCIAL NA ANÁLISE GEOGRÁFICA: CONTRIBUIÇÕES PARA OS ESTUDOS SOCIOAMBIENTAIS}

A contribuição da Teoria das Representações Sociais, desenvolvida pelo psicólogo social francês Serge Moscovici, constitui ferramenta importante para a superação da dicotomia existente entre os estudos sociais e ambientais dentro da análise geográfica. Moscovici (1978) propõe o estudo da construção do conhecimento popular através das representações construídas na correlação entre o material e o simbólico na vida cotidiana. 
Tal proposta mostra-se promissora aos estudos socioambientais, visto que o meio ambiente é estruturado por elementos materiais e simbólicos. Sendo assim, o estudo socioambiental deve integrar os aspectos objetivos e subjetivos dentro das relações espaciais (MENDONÇA, 2002), levando a cabo o conhecimento socialmente elaborado e compartilhado na estruturação da vida cotidiana. Aliás, pode-se afirmar que "o mundo real só pode ser conhecido por representações, que se interpõem entre o sujeito e o objeto. Assim, a história do conhecimento da natureza é a história das representações formuladas sobre a natureza" (SOFFIATI, 2011, p. 30).

Com o lançamento do livro La Psychanalyse: son image e son public, na década de 1960, Moscovici destaca a necessidade de averiguação científica na relação entre o saber científico e o senso comum. Ao fazer isso enfatiza o estudo da constante construção de símbolos e significados que alicerçam a maneira de compreender e se relacionar na e com a realidade (GUERRA, 2016).

Além do mais, o estudo do senso comum, isto é, das representações socialmente construídas no contato com o ambiente, faz-se importante visto que "apreender a complexidade ambiental não constitui um problema de aprendizagens do meio, e sim de compreensão do conhecimento sobre o meio" (MENDONÇA, 2002, p. 121). Por meio dessa compreensão, de como o conhecimento sobre o meio ambiente é construído, estruturado e internalizado, pode-se avançar na análise dos valores e atitudes para com a natureza.

Sem embargo, diante de sua relevância científica, parece importante a apreensão da definição de representação social. Não obstante, o próprio Moscovici opunha-se a isso, uma vez que a mesma ficaria encaixotada conceitualmente dificultando que fosse trabalhada por diferentes ângulos e por múltiplos profissionais. Contudo, alguns autores tomaram a liberdade para fazê-lo. Por exemplo, Sá (1998, p.68) a define como: "uma modalidade de saber gerada através da comunicação na vida cotidiana, com a finalidade prática de orientar os comportamentos em situações sociais concretas". De acordo com Moscovici (2003, p. 48), destaca-se que a importância das representações sociais:

[...] continua a crescer, em proporção direta com a heterogeneidade e a flutuação dos sistemas unificadores - as ciências, religiões e ideologias oficiais - e com as mudanças que elas devem sofrer para penetrar a vida cotidiana e se tornar parte da realidade comum. Os meios de comunicação de massa aceleraram essa tendência, multiplicaram tais mudanças e aumentaram a necessidade de um elo entre, de uma parte, nossas ciências e crenças gerais puramente abstratas e, de outra parte, nossas atividades concretas como indivíduos sociais.

Por conseguinte, essa tendência transitória reverbera na maneira como a sociedade compreende e age perante o meio ambiente. Os meios de comunicação da sociedade moderna, marcados pela geração e transmissão instantânea de dados e informações, acaba por condicionar o entendimento social dos problemas socioambientais gerando representações sociais próprias. Cita-se, a exemplo, o discurso ambientalista que por vezes distorce fatos e fatores para fabricar verdades segundo a conveniência dos interesses econômicos. A sociedade, por fim, internaliza e reproduz tais verdades, segundo as representações 
sociais intencionalmente arquitetadas, que passam a fazer parte do senso comum. Por isso o estudo científico das representações sociais é de grande relevo para a análise geográfica, visto ser instrumento de elucidação e proposição para transformação socioambiental.

Entretanto, para que o estudo das representações sociais se constitua em ferramenta de intervenção e transformação socioambiental, faz-se preciso a compreensão de como as mesmas são construídas. As informações e os hábitos são construídos e transmitidos socialmente. No plano individual, o sujeito acaba por se apossar de um conjunto de saberes que o qualifica como debatedor do assunto em pauta. Consequentemente, a proporção em que "[...] a conversa coletiva progride, a elocução regulariza-se, as expressões ganham em precisão. As atitudes ordenam-se, os valores tomam seus lugares, a sociedade começa a ser habitada por novas frases e visões" (MOSCOVICI, 1978, p. 53).

Diante desse quadro, é válido salientar que "[...] nossas coletividades hoje não poderiam funcionar se não se criassem representações sociais, baseadas no tronco das teorias e ideologias que elas transformam em realidades compartilhadas, relacionadas com as interações entre pessoas [...]" (MOSCOVICI, 2003, p. 48). Destarte, a Teoria das Representações Sociais faz-se imprescindível para a análise das questões socioambientais, posto que a mesma se desdobra na correlação entre a realidade coletiva e a individual dimensionando o senso comum e o comportamento social no ensejo do imaginário construído como fruto das interações subjetivas entre as pessoas.

A problemática ambiental, no bojo dos mecanismos da objetivação e ancoragem que fundamentam a construção das representações sociais (MOSCOVICI, 1978), passa a ser assunto familiar, habitual, corriqueiro. Isto acontece em função da ampla divulgação pelos meios de comunicação dos problemas que enfrentamos cotidianamente. Aquecimento global, inundações, desmoronamentos, a seca, os homicídios, assaltos, furtos, latrocínios, a dengue, a chikungunya, o zika vírus, febre amarela, entre tantos outros problemas socioambientais, possuem presença constante no imaginário coletivo.

A questão é: como a sociedade compreende esse contexto, como as pessoas vivenciam e lidam com essa realidade, o que os indivíduos pensam e sentem em relação ao seu meio ambiente? A Teoria das Representações Sociais, fundamentando a perspectiva da percepção ambiental, evidencia-se como significativo auxílio à ciência geográfica para a busca das respostas a essas indagações.

\section{CONJUNTO CEARÁ: ESPAÇO MULTIFACETADO}

O bairro Conjunto Ceará foi construído na década de 1970 como fruto da política pública contra o déficit habitacional da cidade de Fortaleza. O mesmo está inserido a sudoeste da periferia da cidade, reforçando a imagem de segregação. $\mathrm{O}$ bairro está dividido em 4 etapas (Fig. 2), enumeradas de acordo com a sequência de implantação. 
Figura 2: etapas de implantação do Conjunto Habitacional Ceará.

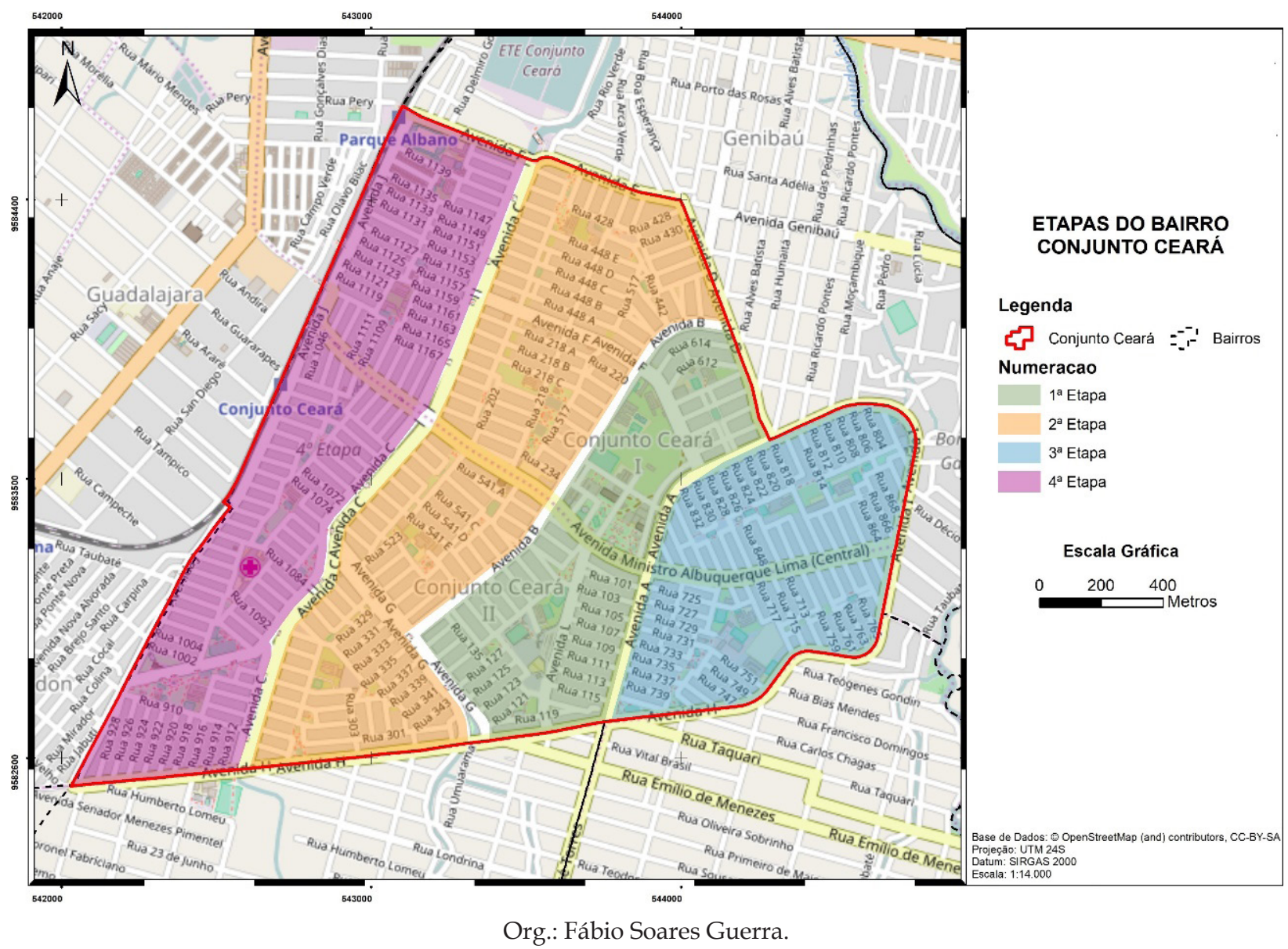

De acordo com o censo demográfico de 2010 (IBGE, 2010), o conjunto habitacional apresenta população de 42.894 habitantes, domiciliados em 12.216 unidades, em uma área de $2.020 \mathrm{~m}^{2}$. Situação que o coloca na condição de um dos mais populosos bairros da capital cearense.

Para entender a evolução socioespacial do bairro, há que analisá-lo no contexto da criação dos conjuntos habitacionais em Fortaleza. Isso nos remete ao crescimento populacional e urbano ocorridos, notadamente, a partir da segunda metade do século XX. Os motivos de tais processos são bem esclarecidos por Costa (2005, p. 52) quando menciona que:

Na segunda metade do século $X X$, a crise da agricultura cearense, a concentração fundiária e os longos períodos de estiagens contribuíram para intensificar as migrações rurais-urbanas e acelerar o crescimento populacional de Fortaleza. Além destes fatores que expulsam o homem do campo, a cidade passa a ser atraente para diferentes grupos sociais, em virtude do desenvolvimento do comércio e da indústria, da implantação de infraestrutura e serviços e da oferta de empregos.

A cidade passa a ser vista como possibilidade de ascensão social para aqueles que eram excluídos pela concentração fundiária e as opressivas relações de trabalho no campo, além das limitações de ordem natural do interior. Nessa nova conjuntura, Fortaleza 
polariza a maior parte das migrações rural-urbano no estado do Ceará, por apresentar infraestrutura, serviços, rede de transporte e um leque de empregos urbanos em franco desenvolvimento.

Deste modo, o crescimento populacional de Fortaleza acentua-se significativamente. Somente na década de 1950 o crescimento demográfico aproximou-se de 50\% em comparação com os anos 1940, nas décadas seguintes o crescimento mostrou-se constante (SOUZA, 2006). "A população de Fortaleza passou de 270.169 em 1950 para 514.813 habitantes, em 1960. Esse crescimento populacional aumentou a defasagem entre o tamanho da população, a oferta de emprego e as condições de infraestrutura e serviços urbanos" (COSTA, 2009a, p. 155-156).

Por consequência, o crescimento populacional supera a capacidade de suporte urbano da capital, destarte a mesma não consegue abrigar a contento e atender às necessidades do novo quantitativo demográfico, ocasionando assim fortes contrastes sociais no espaço (COSTA, 2005; SOUZA, 2006). A cidade cresce de forma desordenada e excludente. Em decorrência, os problemas em relação à saúde, segurança, desemprego, educação, saneamento, moradia, dentre tantos outros, assumem significativa evidência. A falta de moradia digna para a população, que vai ocupando o entorno dos centros industriais e comerciais, preocupa o poder público que passa a adotar medidas contra o processo de favelização da cidade.

Diante esse contexto, sobretudo nas décadas de 1960 e 1970, com o intuito de resolver o déficit habitacional de Fortaleza, os governos militares "passaram a construir conjuntos habitacionais afastados da cidade, agravando com isto o problema dos transportes urbanos, diante da necessidade de deslocamento dos trabalhadores para o local de trabalho" (BERNAL, 2004, p. 157).

No cerne das políticas nacionais de habitação, vários conjuntos habitacionais são construídos em Fortaleza, a partir dos anos 1970, a saber: “Cidade 2000, José Walter, Conjunto Ceará, Beira Rio, Nova Assunção, Santa Luzia do Cocó, dentre outros" (SOUZA, 2006, p. 156). Entretanto, foram construídos em locais distantes das áreas privilegiadas da cidade. Por um lado, o preço dos terrenos e o financiamento das unidades ficavam acessíveis à população de menor renda, por outro, a falta de infraestrutura, saneamento básico, redes de transporte, entre tantos problemas, geravam grandes desconfortos. Observa-se, na verdade, a segregação do espaço urbano pelo próprio Estado.

Dentro desse cenário, em 1976, inicia-se a construção do Conjunto Ceará. Em 10 de novembro de 1977 a 1 $1^{\text {a }}$. etapa é inaugurada, quando 996 unidades são entregues pelo governador Adauto Bezerra (PRODECOM, 1999). Todavia, a realização da casa própria veio acompanhada de vários infortúnios, visto que:

Os primeiros habitantes do conjunto enfrentaram sérios problemas no que se refere às condições de infraestrutura como: saneamento básico, uma vez que nem toda a área foi contemplada com este serviço; inundações nos períodos chuvosos; além de vias inacabadas dificultando o trânsito de veículos e pessoas no interior da área construída (PAIVA, 2010, p. 69). 
Além do que, destaca-se o isolamento "[...] pois o terreno onde se deu a construção do conjunto habitacional era distante dos locais de trabalho como também de difícil acesso a outros serviços como saúde, comércio, dentre outros" (PAIVA, 2010, p 70).

Em 1978 a 2a . etapa ofertou 2.516 casas. No ano de 1979 ocorre a conclusão da $3^{\mathrm{a}}$. etapa, com 2.037 unidades, e em 1981 temos a finalização da $4^{a}$. etapa com 3.115 residências (PRODECOM, 1999). Na década de 1990, com a implantação de diversos equipamentos urbanos (praças, polo de lazer, campos de futebol, centro cultural, etc.) e a oferta de variados serviços (comércio, escolas, posto de saúde, hospital, etc.) o Conjunto Ceará afirma-se como unidade urbana polarizadora dos bairros ao redor, fato reforçado pela criação do terminal rodoviário construído com recursos da prefeitura e entregue a população em 1993.

\section{A RELAÇÃO SOCIEDADE VERSUS MEIO AMBIENTE NO BAIRRO CONJUNTO CEARÁ}

A população do Conjunto Ceará se apropria bem do espaço do bairro. As práticas sociais evidenciadas indicam isso: lazer, estudo, trabalho, religiosidade, enfim. Ademais, a percepção dos moradores em relação ao meio ambiente no qual convivem se mostrou bem aguçada em muitos aspectos.

A maior parcela da população amostral se encontra na faixa etária de 31 a 50 anos (40\%) e o segundo maior grupo etário com 50 anos ou mais (30\%), sendo o restante disposto entre 21 e 30 anos (25\%) e entre 15 e 20 anos (5\%). Espera-se, naturalmente, dessa base empírica a maturidade social necessária para atender às propostas do estudo em questão.

Quanto a escolaridade, $15 \%$ possuem o ensino fundamental, $60 \%$ concluíram o ensino médio e $25 \%$ cursaram o nível superior. Soma-se a isso que o tempo de moradia dos participantes oscila entre 6 a 41 anos de estadia no Conjunto Ceará. Características essas que conferem fundamentação às representações sociais formuladas e, por consequência, a percepção ambiental urbana dos mesmos.

No que diz respeito a percepção quanto ao meio ambiente, as representações apresentadas revelaram a compreensão da dimensão social do referido conceito. Assim, no entendimento de $70 \%$ dos populares o mesmo resulta da "interação entre os aspectos sociais e naturais do espaço geográfico". Fato digno de nota, posto que o senso comum relativiza ou suprime os aspectos humanos na leitura espacial.

A ideia de meio ambiente como integrado unicamente a dimensão natural não prevaleceu, pois somente $25 \%$ dos participantes assinalaram o conceito de meio ambiente como sendo "o mesmo que natureza". A terceira opção dada como resposta foi marcada por $5 \%$ dos moradores, opção que destoa em muito do conceito científico, definindo o meio ambiente como "conjunto de elementos construídos pelo homem".

Reforçando a afirmação que os moradores revelaram aguçada percepção ambiental, no que tange aos recursos hídricos do bairro, destaca-se nas entrevistas indagações sobre a realidade dos córregos canalizados presentes no bairro. A compreensão de que esses recursos carecem de recuperação e requalificação foi notória. Dos moradores que participaram 
do estudo, $100 \%$ os entende como "ambiente com sérios problemas a serem resolvidos". Evidencia-se, pois, forte senso crítico quanto a degradação ambiental.

Além do que, quanto à responsabilidade referente ao grande surto de doenças arboviróticas, o peso da responsabilidade, segundo a percepção dos moradores se configura assim: 80\% imputa à comunidade a responsabilidade do grande surto vivenciado nos primeiros cinco meses de 2017,10\% responsabiliza os córregos e canais, também 10\% sinaliza o Aedes aegypti como motivo principal dos casos registrados.

$\mathrm{Na}$ avaliação da população amostral, um dado importante: $0 \%$ dos moradores, responsabilizou as chuvas pelo grande número de casos. Registro interessante, já que o período chuvoso corresponde historicamente ao período do ano com maior incidência de dengue, zika e chikungunya. Nesse caso, um erro perceptivo poderia ocorrer por associação. Mesmo assim, a percepção ambiental evidenciada aponta para o cerne do problema, a saber, as práticas da comunidade em relação ao descarte incorreto de materiais que acabam por virar logradouro do mosquito Aedes aegypti, que é apenas o vetor de transmissão das citadas doenças.

Em visita ao Hospital e Maternidade Nossa Senhora da Assunção, na quarta etapa do conjunto, constatamos por meio de entrevistas com os profissionais da saúde que nos primeiros meses do ano as arboviroses tiveram prevalência considerável (Tab. 1). Tal cenário interfere nas representações sociais formuladas e, por extensão, condiciona a percepção ambiental dos moradores sobre a questão da saúde pública.

Tabela 1: Casos de arboviroses registrados no atendimento de saúde do Conjunto Ceará, Fortaleza, CE.

\begin{tabular}{l|c|c|c|c|c}
\hline DOENÇAS & JAN./2017 & FEV. / 2017 & MAR./2017 & ABR./2017 & MAIO/2017 \\
\hline DENGUE & 11 & 25 & 72 & 104 & 59 \\
\hline CHIKUNGUNYA & 6 & 7 & 69 & 202 & 112 \\
\hline ZIKA & 2 & 4 & 26 & 36 & 24 \\
\hline
\end{tabular}

Fonte: Fábio Soares Guerra.

Verifica-se, todavia, os meses de março, abril e maio como os de maior incidência das mencionadas doenças. Não por acaso, março e abril são os meses de maior concentração de chuvas do primeiro quinquimestre. Além do que, o mês de maio registra pluviosidade próximo da normal climática. Reafirma-se, contudo, o caráter geossistêmico do meio ambiente, a interdependência entre os fenômenos ambientais. A maior parcela dos entrevistados consegue fazer essa associação: alta pluviosidade = altos índices de arboviroses. “Todo ano é assim, começa a chover e a dengue ataca”, afirma morador da $1^{\text {a }}$. etapa. Falas semelhantes ocorreram ao longo da pesquisa.

Nesse ínterim, a população amostral revelou senso crítico quanto ao serviço prestado por postos de saúde, pelo hospital e pela unidade de pronto atendimento (UPA) do bairro. Em resposta ao questionário aplicado, nenhum morador assinalou o serviço como satisfatório, $40 \%$ o considera regular e $60 \%$ o classifica como insatisfatório. A partir dessa percepção, o comportamento adotado esperado é de participação e pressão sobre o poder público municipal em busca de melhorias. 
A concentração pluviométrica nesse período do ano, atrelada à fisiografia urbana do bairro, gera outros problemas de ordem social. $\mathrm{O}$ transbordamento dos canais, estragos na pavimentação, o escoamento superficial, a erosão dos solos e vertentes, problemas com a mobilidade e a inutilização de aparelhos urbanos são alguns exemplos. Mesmo assim, parte considerável da população não vê a chuva em si como o problema e sim as práticas sociais inadequadas: "enquanto cada um não tiver consciência e fizer sua parte para combater o mosquito vai ser sempre assim", diz morador da $2^{a}$. etapa.

O mau planejamento e a ineficaz gestão do espaço ambiental urbano são também apreendidos pelas representações dos moradores que, de acordo com a percepção desenvolvida, mencionam: "a prefeitura e os políticos não estão preocupados em fazer alguma coisa para consertar o bairro", menciona morador da $4^{\mathrm{a}}$. etapa. O descaso com os equipamentos urbanos reforça tal percepção (Fig. 3).

Figura 3: Quadra poliesportiva na Av. G, tomada pelo mato.

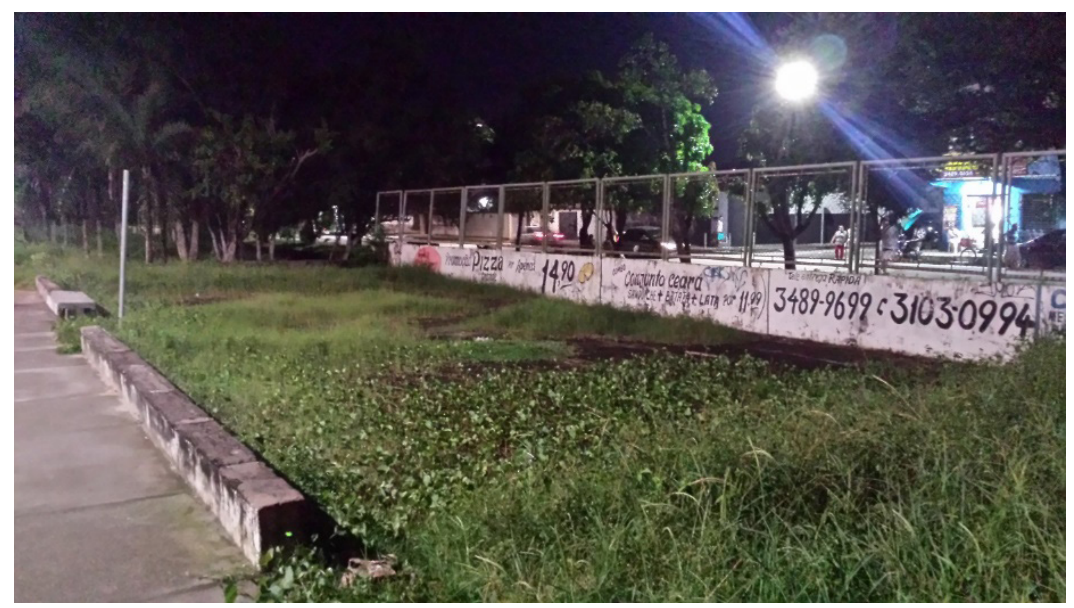

Fonte: Fábio Soares Guerra.

Muito embora seja verificada significativa apropriação socioespacial da comunidade, com diversificado espaço ação, espaço atividade, espaço utilidade e topofilias, é notório o intenso sentimento de insegurança.

No universo entrevistado, $80 \%$ se sente inseguro no Conjunto Ceará e 55\% foi vítima de algum crime. Por certo, essa realidade influencia as representações sociais formuladas condicionando a maneira de perceber e agir cotidianamente. Quando indagados sobre qual etapa é a mais perigosa observou-se que a $4^{\mathrm{a}}$. etapa do bairro foi apontada por $65 \%$ dos participantes, a $1^{\mathrm{a}}$. e a $3^{\mathrm{a}}$. etapas empatam com $15 \%$ de rejeição, em menor proporção a $2^{\mathrm{a}}$. etapa com 5\%. Temos aqui, no âmbito do espaço geral do espaço habitado, a evidência da $4^{a}$. etapa do bairro como uma topofobia. Entretanto, a maior ocorrência de crimes contra os entrevistados, segundo suas respostas, aconteceu na $1^{\mathrm{a}}$. etapa (5 ocorrências) e na $4^{\mathrm{a}}$. etapa foram apontadas 3 ocorrências apenas. Registra-se aqui uma dissonância perceptiva, onde o sentimento (sensação em relação à segurança) e o fato objetivo (o crime sofrido) não se coadunam. Por outro lado, podemos inferir que a insegurança em relação a $4^{\mathrm{a}}$ etapa pode surgir pelo conhecimento de crimes ocorridos com terceiros, que não foram incluídos na 
população amostral (vizinhos, parentes, amigos). Porventura, sendo esse o caso, teremos uma compatibilização entre a insegurança e a ocorrência de crimes. Porém, essa possível compatibilidade estrutura-se entre o sentimento (sensação de insegurança) e fato subjetivo (o crime sofrido por terceiros).

Além disso, o preconceito em relacionar a baixa condição social à criminalidade tem sua parcela de responsabilidade em se apontar a $4^{\mathrm{a}}$. etapa como a mais perigosa, dado que a mesma se insere na divisa com localidades de baixo poder aquisitivo: Granja Lisboa, Jurema (município de Caucaia), Genibaú. “A $4^{\mathrm{a}}$. etapa é a mais perigosa porque está perto de várias favelas, os ladrões vêm de fora para roubar aqui", relata morador da própria etapa. Como reforço a essa percepção, a $4^{\mathrm{a}}$. etapa é a que recebe menos estrutura e assistência do poder público municipal. Nota-se, pois, outra correlação interessante: embora apenas $20 \%$ da população amostral se sinta segura no bairro, $45 \%$ dos participantes nunca foram vitimados em etapa alguma. Contudo, o sentimento de insegurança impera em $80 \%$ dos moradores entrevistados. Ademais, 25\% dos entrevistados apontou uma etapa como a mais perigosa, no entanto, foram vitimados em outra, reforçando mais uma vez o descompasso entre o sentimento e o fato objetivo. Essa incongruência pode ser explicada, entre outros fatores, pelo sensacionalismo dos programas policiais, além de grupos em redes sociais nos quais os moradores notificam a ocorrência de crimes e postam vídeos dos mesmos. A geração instantânea e a rápida divulgação das informações exacerbam o sentimento de medo.

Diante esse contexto, naturalmente, é de se esperar que o bairro em si deva se configurar nas representações sociais formuladas pelos seus moradores como espaço de topofobia. Daí a percepção desenvolvida condicionaria comportamentos de aversão ao local de morada. Não obstante, quando indagados se desejariam residir em outro bairro apenas 30\% disseram que gostariam - a maioria dos participantes estão satisfeitos em morar no Conjunto Ceará. Percebe-se aqui outro descompasso, nesse caso entre sensação e desejo. Da população amostral 80\% não se sente segura no Conjunto Ceará, outrossim $70 \%$ não deseja morar em outro lugar.

Alguns fatores de infraestrutura podem justificar essa dissonância, dentre eles, destacamos a variedade do transporte público (terminal de ônibus, serviços de táxi e moto táxi, trem, vans), serviços bancários, comércio, correio, escolas estaduais, municipais e particulares, vila olímpica e centro cultural, conselho tutelar, agência do Detran, postos de saúde e unidade de pronto atendimento (UPA), hospital e maternidade, delegacia e batalhão da polícia militar, corpo de bombeiros, autoescolas, etc. Além disso, são fatores importantes o tempo de residência e as relações de amizades fortalecidas pela própria arquitetura do bairro, construído sob o conceito urbanístico de unidade de vizinhança, que reforçam o vínculo afetivo entre a população e o espaço de vivência.

Não por acaso 43 \% dos moradores afirmou ter forte vínculo afetivo com o bairro, 39\% apresentou moderado vínculo afetivo e apenas 18\% mencionou não ter veículo nenhum com o Conjunto Ceará. Entre forte e moderado vínculo afetivo soma-se $82 \%$ dos entrevistados, o que justifica o forte apego a localidade. Assim, o bairro como um todo, segundo as representações de seus moradores, configura exemplo de topofilia. 
O espaço do bairro é percebido por seus moradores para além da simples função da moradia, 70\% o concebe como lugar de trabalho, lazer e recreação. Nessa conjuntura, detectamos dentro do raio do espaço-ação vários espaços-atividade e espaços-utilidade. Notadamente as praças e as calçadas das avenidas centrais (espaços-utilidade) salientam-se como espaço de socialização e de práticas sociais modernas e tradicionais. A prática da caminhada e de exercícios físicos (futebol, ginástica, etc.) ao longo dos calçadões e praças é recorrente, principalmente entre o final da tarde e à noite. Outrossim, a venda de lanches nesses mesmos espaços cresce a cada dia, além de outras práticas de comércio ambulante (circuito inferior da economia), transformando o espaço utilidade em espaço-atividade. Consequentemente, ao longo do dia, dentro de um espaço-ação (o bairro em si) temos a alternância na configuração da paisagem, ora apresentando o espaço-ação como espaço-utilidade, ora como espaço-atividade.

A avenida Ministro Albuquerque Lima, as av. A, B, C, D, G, H e J concentram uma gama de serviços (bancos, lojas, lotéricas, farmácias, comércio, etc.). Tais espaços conjugam atividades profissionais e de lazer, com intenso fluxo de pessoas. Notadamente, são as topofilias que mais se expressam dentro do espaço-ação.

Práticas sociais tradicionais resistem a mudança dos hábitos e ao novo cenário metropolitano. Como exemplo, o hábito de sentar à calçada para conversar com os vizinhos no fim de tarde. É bem verdade que a insegurança e os registros de ocorrência criminal restringem tal hábito a alguns lugares, não obstante, é uma prática ainda perceptível.

Verifica-se também, entre as práticas sociais que resistem à força da pós-modernidade, relações sociais tradicionais como a compra no 'fiado' como fundamento de relações diretas entre as pessoas. Também se revela presente a resistência de profissões tradicionais como relojoeiro, barbeiro, sapateiro, costureira, entre outras.

Portanto, ao analisar as representações que formulam a percepção ambiental dos moradores do Conjunto Ceará nota-se forte dinâmica urbana, práticas econômicas equivalentes às de médias e grandes cidades, a coadunação entre hábitos culturais tradicionais e contemporâneos, percepção e senso crítico apurados em vários aspectos. Percebe-se, sobretudo, a conformação de uma nova urbanidade.

\section{EDUCAÇÃO AMBIENTAL: CONTRIBUIÇÕES À PERCEPÇÃO AMBIENTAL PARA A RELAÇÃO COMUNIDADE VERSUS BAIRRO}

A Educação Ambiental mostra-se como ferramenta importante para o salutar convívio socioambiental. Sendo um processo permanente visando orientar as percepções e práticas espaciais de maneira a garantir a sustentabilidade do ambiente. Nada obstante, a mesma deve ser trabalhada entendendo-se como uma educação política que

(...) está comprometida com a ampliação da cidadania, da liberdade, da autonomia e da intervenção direta dos cidadãos e das cidadãs na busca de soluções e alternativas que permitam a convivência digna voltada para o bem comum (REIGOTA, 2012, p. 13). 
Outrossim, para a realização de trabalho com Educação Ambiental mostra-se importante a apreensão do conceito de meio ambiente, visto ser o ponto de partida do referido processo educativo (GUERRA, 2016). Não eventualmente, a dimensão social é omitida nas discussões e trabalhos acerca do supracitado conceito. Tal tendência apresenta-se como grave deficiência epistemológica. Assim, é válido apoiar-se na definição de Reigota (2012, p. 36), compreendendo-o como

[...] um lugar determinado e/ou percebido onde estão em relação dinâmica e em constante interação os aspectos naturais e sociais. Essas relações acarretam processos de criação cultural e tecnológica e processos históricos e políticos de transformação da própria natureza e da sociedade.

Os conceitos e definições de meio ambiente podem variar de acordo com a especialidade profissional dos autores, porém, para os estudos de percepção ambiental o meio ambiente não pode ser entendido como sinônimo de meio natural. Para maior aprofundamento analítico, a inserção dos aspectos sociais é impreterível. Optou-se, então, por investigar como a Educação Ambiental vem sendo trabalhada pela Geografia no ensino formal, e qual contribuição vem oferecendo em termos de percepção para a comunidade na qual está inserida.

Desta forma, visitou-se uma escola municipal de ensino fundamental, para entrevistas, análises e ponderações. A professora entrevistada é formada em Pedagogia e leciona a disciplina de Geografia em turmas de $3^{\circ}, 4^{\circ}$ e $5^{\circ}$ anos do fundamental I. Quando perguntada sobre seu entendimento do que venha a ser o meio ambiente, respondeu: "é a representação de tudo que temos no espaço em que vivemos". A professora evidenciou uma percepção que pressupõe a conjugação dos elementos naturais e culturais da paisagem geográfica. Tal compreensão de meio ambiente vai, por certo, direcionar suas práticas pedagógicas.

Para a professora, a Educação Ambiental revela-se como "a consciência do nosso ambiente, dos nossos cuidados e da reflexão de nossas atitudes negativas". Registra-se aqui três elementos básicos das representações que balizam sua percepção: consciência, atitude e reflexão. As três categorias salientadas são fundamentos da práxis educativa, onde a reflexão subsidia a consciência que, por sua vez, condiciona o comportamento.

Tendo a percepção ambiental como "a percepção do nosso ambiente", a docente entrevistada trabalha as atividades ambientais perceptivas com o uso de "imagens em livros, mapas, globo terrestre, confecção de maquete e aulas de campo". Essa metodologia adotada propicia situação na qual o aluno será estimulado em termos de percepção por estar em contato com a realidade concreta. O objetivo, pois, é "tornar os alunos críticos quanto sua forma de perceber o ambiente e conscientes de que suas atitudes diárias influenciam diretamente no meio ambiente".

Verifica-se que nesse caso o trabalho com a Educação Ambiental tem seguido orientação condizente com a perspectiva de uma educação emancipatória. O aluno sai da condição de espectador para protagonizar o processo de construção do ensino, o desenvolvimento da consciência e criticidade, da cidadania, de valores e atitudes que reforçarão a percepção da sustentabilidade socioambiental. 
Entretanto, ao entrevistar um grupo de cinco alunos (as), na faixa etária entre 10 e 12 anos, dentre as turmas em que a professora participante leciona Geografia, constata-se que a dimensão dos aspectos sociais não aparece nas representações que formulam sobre o meio ambiente. Quatro estudantes afirmaram ser o meio ambiente "o mesmo que natureza", e um o definiu como o "cuidar do ambiente". Essas representações sociais mostraram-se muito dissonante do almejado em termos de percepção ambiental.

Acerca do entendimento sobre Educação Ambiental, quatro estudantes afirmaram saber do que tratava. Assim, registra-se como respostas: "sim, não poluir o ambiente, nem os rios"; "sim, é respeitar a natureza"; "é cuidar da natureza, não maltratar os animais e não jogar lixo nas ruas"; "sim, as pessoas ajudarem não jogarem lixo nos rios e não poluir água e economizar água". Diante das respostas dadas, a representação social de Educação Ambiental que mais se destacou foi a de 'não poluir', isso os leva a percebê-la como uma atitude de cuidado, um comportamento responsável. A perspectiva reflexiva e propositiva não foi verificada.

Sobre os problemas ambientais do bairro, os mais apontados foram: o lixo, a sujeira dos canais, o mato e as queimadas. Isso mostra que os alunos (as) são capazes de compreender e apontar problemas ambientais urbanos.

Em contato com o núcleo gestor e o corpo docente, foi proposta a Ecopedagogia como possibilidade de trabalho com a Educação Ambiental visando o estímulo da percepção. Esta abordagem configura-se como basilar à educação voltada para as questões socioambientais, pois:

A Ecopedagogia visa à consolidação de uma consciência ecológica ampla, profunda e difusa. Para tanto, há de se investir em mudanças culturais que afetam a mentalidade, o comportamento como modo de pensar e agir, a cultura política, a visão de mundo, as representações sociais, a solidariedade e a participação. É a tentativa de desenhar e arquitetar a adoção de pontos de vista, de práticas e de movimentos sociais, assim como projetos políticos que deem conta dos dilemas ambientais da atualidade (RUSCHEINSKY, 2002, p. 67).

A percepção ambiental, constatada por meio da investigação das representações sociais em parcela dos moradores do bairro, é de que os recursos naturais são de fato entidades coisificadas, no entanto, dotadas de valor de uso e troca com caráter utilitarista. Como exemplo tem-se as margens do canal da Av. G (Fig. 4), que não raro é utilizada como local de despejo de lixo ou entulho. Nesse caso, verifica-se a equivocada percepção de que o córrego é meio de descarte, não havendo o entendimento geossistêmico do meio ambiente. 
Figura 4: Margem direita do canal da Av. G.

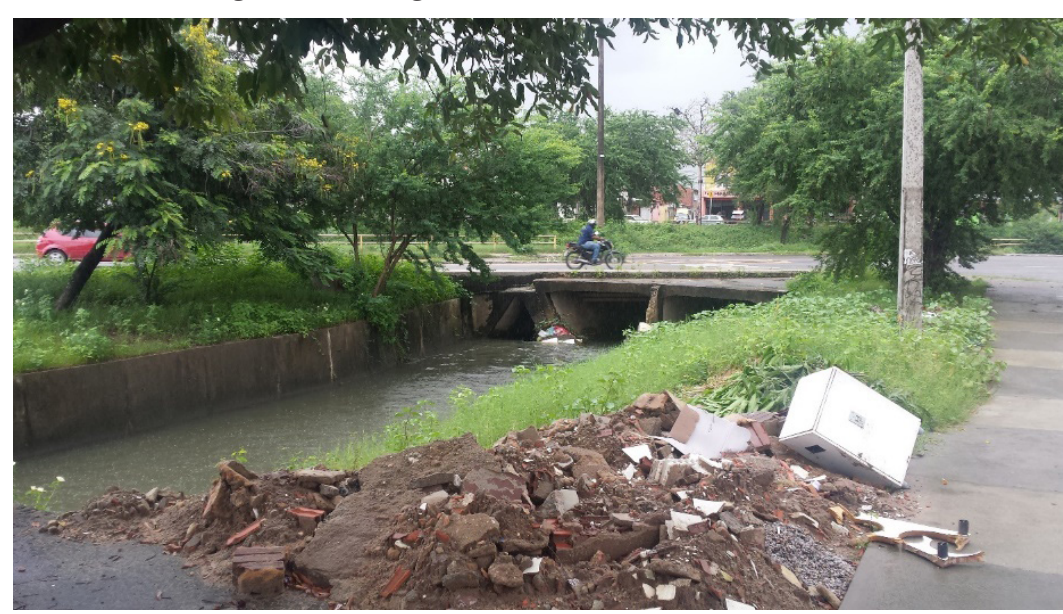

Fonte: Wandersa Cordeiro Magalhães Guerra.

A vertente ecopedagógica, fundamentada na pedagogia da práxis, deve ser trabalhada de modo a reorientar as representações sociais construídas acerca dos recursos hídricos do bairro, modificando assim a percepção dos moradores sobre a importância e a dinâmica ambiental de tais recursos. A Educação Ambiental, por meio da escola básica, é de grande relevo nesse sentido.

A montante da Av. G, na 2a . etapa do Conjunto Ceará, o córrego perpassa o bairro Granja Portugal (Fig. 5), cujas duas margens estão ocupadas desordenadamente por domicílios que despejam dejetos no córrego. Registra-se nesse caso, a representação do recurso hídrico como meio de saneamento, reforçando a percepção de que a natureza deve se encarregar de nossos dejetos. A qualidade do ambiente como condição necessária para o equilíbrio geoecológico, como impreterível para promoção da saúde coletiva, não se apresenta como representação social por parte dos moradores locais. Por extensão, a percepção ambiental construída apresenta-se aquém do desejado.

Figura 5: Córrego na divisa entre os bairros Granja Portugal e Conjunto Ceará.

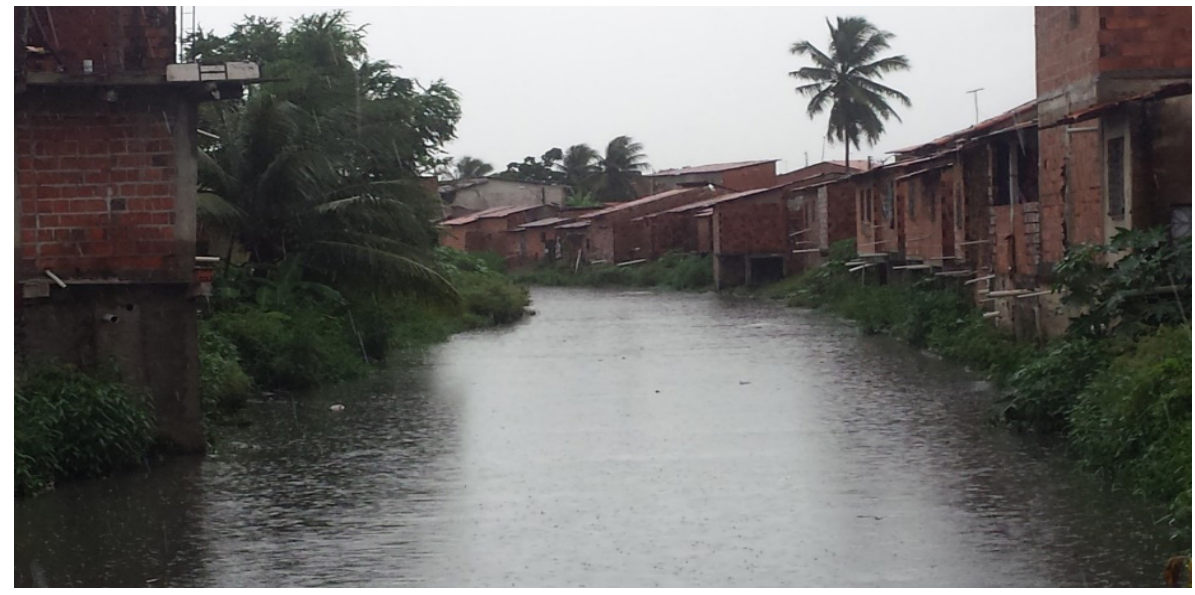

Fonte: Fábio Soares Guerra. 
Lamentavelmente, diante de cenários assim resulta-se no que destaca Guerra (2016, p. 81):

O que ocorre é a naturalização da precariedade socioambiental, assim córregos são entendidos como via de escape para dejetos, os alagamentos são problemas de ordem climática, a dengue é culpa do mosquito, as áreas verdes são apenas mato e mato é lixeira pública. Essa realidade, infelizmente, conduz a construção das representações sociais sobre a natureza e nossa responsabilidade sobre ela.

A coleta de lixo constitui outro problema. A Prefeitura Municipal de Fortaleza é responsável pelo recolhimento do lixo do bairro em dias e horários pré-determinados. Contudo, como o bairro não possui pontos específicos para alocar o lixo, este é colocado em qualquer lugar externo às residências.

A Educação Ambiental, por meio da Geografia Escolar, através de aulas de campo e estudos dirigidos, poderia explorar essas localidades de modo a destacar o porquê de a paisagem apresentar estrutura degradada (Figs. 4 e 5), além de suas consequências para o contexto socioambiental da comunidade. Essa metodologia coloca o aluno como protagonista na construção do conhecimento, em consonância com a abordagem socioconstrutivista, uma vez que a mesma leva em conta a interação entre os aspectos culturais, sociais e linguísticos na investigação da origem e desenvolvimento do pensamento e comportamento humano (VYGOTSKY, 2007).

Para a construção de representações e percepções construtivas em relação ao meio ambiente, destacaremos três conceitos importantes a serem trabalhados pela escola básica no contexto do conjunto habitacional estudado, a saber: vulnerabilidade socioambiental, percepção de risco ambiental e sustentabilidade.

O primeiro, está relacionado a percepção do tipo de ambiente vivenciado pela comunidade, além do que seria apropriado como ambiente saudável e necessário para o equilíbrio ecossocial. De acordo com Costa (2009b, p. 145):

A vulnerabilidade é uma noção multidimensional, à medida que afeta indivíduos, grupos e comunidade em planos distintos de seu bem-estar, de diferentes formas e intensidade. A vulnerabilidade social de pessoas, famílias ou comunidade são entendidas como uma combinação de fatores que possam produzir uma deterioração de seu nível de bem-estar, em consequência de sua exposição a determinados tipos de riscos.

A fundamentação do entendimento de vulnerabilidade deve ser trabalhada em sala de aula, em conformidade com a faixa etária de cada turma. A apreensão e internalização do conceito citado auxiliará o educando a não naturalizar a precarização ambiental, levando-o a perceber a real condição em que vive e a possibilidade de superação e transformação do ambiente.

Entretanto, para que a transformação socioambiental possa ocorrer de maneira a atender aos anseios da comunidade, o segundo conceito sugerido também deve conduzir as práticas de Educação Ambiental, qual seja, a percepção de riscos ambientais. Segundo Souza e Zanella (2009, p. 16) podemos concluir que os riscos devem ser tratados como 
[...] resultado da intricada relação entre ameaça e vulnerabilidade, que apresentam uma profunda dependência entre si. A noção de risco se estabelece com base na relação conflituosa entre o homem e o seu ambiente, em um processo de mútua influência. Portanto, deve-se procurar também rejeitar a ideia maniqueísta da existência de um evento natural agressor atuando sobre uma sociedade que, por sua vez, é tida como vítima.

Assim, a população deve desenvolver a percepção de riscos ambientais para entender o que deve ser transformado, evitado ou reforçado para garantir a qualidade socioambiental. Perante o quadro descrito até então, indaga-se: qual a representação social que fundamenta a percepção ambiental dos moradores? Que tipo de convivência é estabelecida pela comunidade? Quais os riscos envolvidos em morar no bairro Conjunto Ceará? A Geografia Escolar, por meio de práticas em Educação Ambiental, pode trabalhar essas questões estimulando a percepção de riscos ambientais.

O terceiro conceito proposto para o trabalho com Educação Ambiental no contexto da Geografia Escolar é o de sustentabilidade. Para Dias (2002, p. 64) o desenvolvimento sustentável é "compatibilizar o atendimento das necessidades sociais e econômicas do ser humano com as necessidades de preservação do ambiente e dos recursos naturais, de modo que assegure a sustentabilidade da vida na Terra" para as gerações presentes e futuras.

A compreensão acerca da sustentabilidade conduzirá às representações sociais positivas sobre a coadunação entre crescimento econômico e preservação ambiental. Assim, a percepção de crescimento e desenvolvimento surgirá calcada no critério da racionalidade ambiental.

A Ecopedagogia exige a práxis pedagógica, a transposição da educação bancária. Isso por si justifica sua aplicação. $\mathrm{O}$ educando deve ser colocado em contato com a realidade estudada, deve ser colocado na posição central da relação de ensino - aprendizagem (GUERRA, 2016). Nada obstante, diante disso, necessita-se uma:

[...] ecopedagogia e de uma ecoformação hoje, precisamos de uma Pedagogia da Terra, justamente porque sem essa ecopedagogia para a "re-educação" do homem/ mulher, principalmente do homem ocidental, prisioneiro de uma cultura cristão predatória, não podemos mais falar da terra como um lar, como uma toca para o "bicho homem" como dizia Paulo Freire. Sem uma educação para a vida sustentável, a Terra continuará sendo considerada como espaço do nosso sustento e de nosso domínio técnico-tecnológico, um ser para ser dominado, objetos de nossas pesquisas, ensaios e, algumas vezes, de nossa contemplação (GADOTTI, 2009, p. 63).

O corpo docente da escola municipal estudada, não apenas os professores de Geografia, possui na comunidade um grande laboratório para trabalhos ecopedagógicos aplicados com Educação Ambiental para o despertar da percepção ambiental.

A comunidade deve ser levada a perceber a estruturação da realidade na qual está inserida. Desta forma, será possível a construção de valores e atitudes para a transformação socioambiental. Assim, "é necessário estabelecer uma Educação Ambiental por meio de uma visão integrada para o planejamento e gestão sustentável” (PAULA; SILVA; GORAYEB, 
2014, p. 514). A Educação Ambiental, por meio da Ecopedagogia, é capaz de redirecionar as representações sociais que fundamentam a percepção ambiental desejada para o salutar convívio entre os moradores do Conjunto Ceará e o meio ambiente.

\section{CONSIDERAÇÕES FINAIS}

Durante a pesquisa foi possível constatar que a comunidade possui percepção ambiental de muitos aspectos averiguados: na conceituação de meio ambiente, na imputação de responsabilidade quanto ao surto de arboviroses, sobre a degradação ambiental dos córregos, sobre a segurança, prestação de serviços, assistência à saúde. Além disso, é notório o forte apego afetivo ao espaço vivido cotidianamente.

Contudo, a população amostrada, em boa medida, percebe o meio ambiente em escala local. Isso produz e reproduz um grande problema que é a adoção de posturas e atitudes positivas imediatas, de quando em quando, não se configurar necessidade de primeira ordem. A noção de totalidade e a perspectiva sistêmica, desta forma, muitas vezes são suprimidas na percepção ambiental dos moradores do Conjunto Ceará.

Percebe-se também a dificuldade, visto a complexidade dos conflitos de interesses e de percepção, em aplicar com eficiência o planejamento e a gestão socioambiental. Transpor esse obstáculo pressupõe alguns desafios como reorientar a noção de cidadania, revitalizar valores e contrariar a conveniência econômica.

É preciso avançar no entendimento da crise ambiental e de como atitudes e ações locais apresentarão repercussões globais. Com base nessa compreensão, o conceito de cidadania ambiental toma importância, sendo necessário estimular sua constante construção por meio de trabalhos com a percepção do ambiente.

Princípios sustentáveis devem dirigir as práticas sociais cotidianas, sustentando assim a percepção de que as necessidades humanas são, na verdade, as necessidades do meio ambiente. $\mathrm{O}$ homem e o meio ambiente mantêm uma relação contínua e recíproca, sendo que o segundo é condição de existência do primeiro.

O estudo da Geografia da Percepção, além do mais, apresenta-se como contribuição à superação da dicotomia Geografia Física/Geografia Humana, um avanço epistemológico em relação às analises setorizadas. O estudo geográfico deve focar na compreensão holística, tendo como pilar o pensamento complexo. As análises socioambientais devem ser "por um lado, um pensamento capaz de refletir sobre os fatos e de organizá-los para deles obter conhecimento não só atomizado, mas também molar, e, por outro, um pensamento capaz de conceber o enraizamento dos valores numa cultura e numa sociedade" (MORIN, 2000, p. 122). Essa compreensão deve pautar o gerenciamento socioambiental como premissa fundamental.

Desta forma, sobremaneira as políticas públicas de gestão e ordenamento territorial não podem ser norteadas exclusivamente pelo pragmatismo técnico - a dimensão subjetiva e a dinâmica social carecem de mais espaço nesse sentido. O estudo da percepção ambiental 
fornece subsídios para a compreensão de posturas e comportamentos adotados, por isso a construção de políticas sociais não pode renegá-lo.

Assim sendo, o poder público na gestão do espaço urbano deve olhar para o olhar (ou interpretação) da população ali inserida. Antes de intervir no contexto socioespacial, é preciso compreender o indivíduo e daí a coletividade. Desta maneira, avançar-se-á em suprir os anseios e solucionar os problemas vividos na periferia.

\section{REFERÊNCIAS}

ANDRADE, Manuel Correia de. Geografia, ciência da sociedade. São Paulo: Atlas, 1987.

BERNAL, Cleide. A Metrópole Emergente: a ação do capital imobiliário na estruturação urbana de Fortaleza. Fortaleza: Ed. UFC, 2004.

COSTA, Maria Clélia Lustosa. Fortaleza: expansão urbana e organização do espaço. In: SILVA, José Borzacchiello; CAVALCANTE, Tércia Correia; DANTAS, Eustógio Wanderley Correia (Orgs). Ceará: um novo olhar geográfico. Fortaleza: Edições Demócrito Rocha, 2005. p. 51-100.

- Planejamento e expansão urbana. In: DANTAS, Eustógio Wanderley Correia; SILVA, José Borzacchiello; COSTA, Maria Clélia Lustosa (Orgs). De cidade a metrópole: (Trans)formações urbanas em Fortaleza. Fortaleza: Ed. UFC, 2009a. p. 143-185.

Arranjo familiar e a vulnerabilidade na região metropolitana de Fortaleza. In: DANTAS, Eustógio Wanderley Correia; COSTA, Maria Clélia Lustosa (Org.) Vulnerabilidade socioambiental na região metropolitana de Fortaleza. Fortaleza: Ed. UFC, 2009b. p. 139-164.

DIAS, Genebaldo Freire. Iniciação à temática ambiental. São Paulo: Gaia, 2002.

DINIZ, Alexandre Magno Alves. Análise do sentimento de insegurança em Belo Horizonte. In: SIMPÓSIO NACIONAL SOBRE GEOGRAFIA, PERCEPÇÃO E COGNIÇÃO DO MEIO AMBIENTE. 1, 2005, Londrina. Anais... Londrina: Ed. UEL, 2005, p. 1-13.

GADOTTI, Moacir. Educar para a sustentabilidade: uma contribuição para a década da educação para o desenvolvimento sustentável. São Paulo: Editora e Livraria Instituto Paulo Freire, 2009.

GUERRA, Fábio Soares. Entraves didáticos e metodológicos da Educação Ambiental no contexto de escolas básicas no município de Fortaleza-CE: reflexões e perspectivas. 2016. Monografia (Especialização em Educação Ambiental) - Universidade Estadual do Ceará, UECE, Fortaleza - CE.

IBGE - INSTITUTO BRASILEIRO DE GEOGRAFIA E ESTATÍSTICA. Censo Demográfico de 2010. Disponível em: <www.ibge.gov.br>. Acesso em: 01 fev. 2017.

LENCIONI, Sandra. Região e Geografia. São Paulo: Ed. USP, 2003.

MENDONÇA, Francisco. Geografia socioambiental. In: ; KOZEL, Salete (Org.) Elementos de epistemologia da Geografia contemporânea. Curitiba: Ed. UFPR, 2002 p. 121-143.

MERLEAU-PONTY, Maurice. Fenomenologia da percepção. 2. ed. São Paulo: Martins Fontes, 1999.

Conversas - 1948. São Paulo: Martins Fontes, 2004.

MORIN, Edgar. Ciência com consciência. Rio de Janeiro: Bertrand Brasil, 2000.

MOSCOVICI, Serge. A representação social da psicanálise. Rio de Janeiro: Zahar, 1978.

Representações sociais: investigações em psicologia social. Petrópolis: Vozes, 2003.

OLIVEIRA, Lívia; MACHADO, Lucy Marion Philadelpho. Percepção, Cognição, Dimensão Ambiental e Desenvolvimento com Sustentabilidade. In: VITTE, Antônio Carlos; GUERRA, Antônio José Teixeira (Orgs.) Reflexões sobre a Geografia Física no Brasil. 3 ed. Rio de janeiro: Bertrand Brasil, 2010. cap. 5, p. 129-152. 
Percepção Ambiental. Revista Geografia e Pesquisa, Ourinhos, v.6, n.2, p. 56-72, 2012.

PAIVA, João Paulo Matias. Análise microclimática em conjuntos habitacionais: o caso do Conjunto Ceará - Fortaleza/CE. 2010. Dissertação (Mestrado em Geografia) - Universidade Estadual do Ceará, UFC, Fortaleza - CE.

PRODECOM. Conjunto Ceará: Polo de Desenvolvimento. Fortaleza, 1999.

PAULA, Eder Mileno Silva; SILVA, Edson Vicente; GORAYEB, Adryane. Percepção ambiental e dinâmica geoecológica: premissas para o planejamento e gestão ambiental. Sociedade \& Natureza, Uberlândia, v. 26, n. 3, p. 511-518, 2014.

REIGOTA, Marcos. O que é educação ambiental. São Paulo: Brasiliense, 2012.

RUSCHEINSKY, Aloísio. As rimas da Ecopedagogia: uma perspectiva ambientalista. In: (Org.)

Educação Ambiental: abordagens múltiplas. Porto Alegre: Artmed, 2002. p. 61-71.

SÁ, Celso Pereira. A construção do objeto de pesquisa em Representações Sociais. Rio de Janeiro: Ed. UERJ, 1998.

SOFFIATI, Arthur. Fundamentos Filosóficos e Históricos para o exercício da ecocidadania e da ecoeducação. In: LOUREIRO, Carlos Frederico Bernardo Educação ambiental: repensando o espaço da cidadania. 5. ed. São Paulo: Cortez, 2011. p. 27-72.

SOUZA. Maria Salete. Segregação socioespacial em Fortaleza. In: SILVA, José Borzacchiello; DANTAS, Eustógio Wanderley Correia; ZANELLA, Maria Elisa; MEIRELLES, Antônio Jeovah Andrade (Orgs.). Litoral e Sertão: natureza e sociedade no Nordeste Brasileiro. Fortaleza: Expressão Gráfica, 2006. p. 149161.

SOUZA, Lucas Barbosa; ZANELLA, Maria Elisa. Percepção de Riscos Ambientais: teoria e aplicações. Fortaleza: Ed. UFC, 2009.

TUAN, Yi-Fu. Topofilia: um estudo da percepção, atitudes e valores do meio ambiente. São Paulo: DIFEL, 1980.

VYGOTSKY, Lev Semenovich. A formação social da mente: o desenvolvimento dos processos psicológicos superiores. São Paulo: Martins Fontes, 2007.

WOLPERT, Julian. Behavioral aspects of the decision to mifrate. Papers in Regional Science, v.15, p. 15972, 1965.

Data de submissão: 13/jul./2017

Data de aceite: 15/maio/2018 